\title{
War and the Business Corporation
}

\author{
By: Eric W. Orts
}

William Davidson Working Paper Number 427

December 2001 


\title{
War and the Business Corporation
}

\author{
Eric W. Orts ${ }^{*}$
}

December 14, 2001

Please do not cite or quote without the author's permission.

* Professor of Legal Studies, The Wharton School, University of Pennsylvania. For comments, I thank my colleagues, Steve Kobrin, Curtis Reitz, Richard Shell, and Alan Strudler, as well as participants at presentations of earlier versions at the University of Michigan Business School, Vanderbilt Law School, and the Wharton School. 
William Davidson Institute Working Paper 427

If looks could kill, they probably will,

In games without frontiers - war without tears.

- Peter Gabriel

This article addresses the topic of war, which is not ordinarily considered germane to

academic studies of corporate law. A few cases from the Vietnam era are sometimes included in contemporary corporation casebooks..$^{6}$ But in an academic milieu dominated by considerations and calculations of economic costs and benefits, mainstream corporate law teachers tend recently to avoid thinking seriously about issues of business ethics and social responsibility. Two of the most prominent professors of corporate law, for example, have gone so far as to claim that "the recent dominance of a shareholder-centered ideology of corporate law among the business, government, and legal elites in key commercial jurisdictions" has resulted in a world in which "[t]here is no serious competitor" to this view of the corporation. "The triumph of the shareholder-oriented model of the corporation over its principal competitors," these two authors conclude, "is now assured, even if it was problematic as recently as twenty-five years ago." They therefore declare "the end of history in corporate law" and predict that "the ideological and competitive attractions of the standard model will become indisputable" with "convergence in most aspects of the law and practice of corporate governance . . sure to follow., 5

1 Cf. Bert S. Prunty, Jr., Love and the Business Corporation, 46 VA. L. REV. 467 (1960).

${ }^{2}$ E.g., State ex rel. Pillsbury v. Honeywell, Inc., 191 N.W.2d 406 (Minn. 1971) (refusing a shareholder's right to corporate records regarding weapons and munitions manufacture when request is made for a political purpose, namely, opposing U.S. involvement in the Vietnam War); Medical Comm. for Human Rights v. SEC, 432 F.2d 659 (D.C. Cir. 1970), vacated and dismissed as moot, 404 U.S. 403 (1972) (addressing SEC's decision on allowing Dow Chemical Company's refusal to submit a shareholder proposal on the use of napalm "on or against human beings" on grounds of a securities regulation exception for "ordinary business" matters). (2001)

3 Henry Hansmann \& Reinier Kraakman, The End of History for Corporate Law, 89 GEO. L.J. 439,439

4 Id. at 468 .

5 Id. at 439, 468. The unspoken reference is to the controversial claim in social theory more generally of "an end of history" after the Cold War. See FrAncis FuKUYAMA, ThE END OF History AND THE LAST MAN (1993); HowARD Williams ET AL., FRANCIS FUKUYAMA AND THE END OF History (1999). Other leading academics in corporate law agree that a convergence in corporate governance regimes is likely to occur globally, but disagree about the form of this convergence. See, e.g., John C. Coffee, The Future as History: The Prospects for Global 


\section{William Davidson Institute Working Paper 427}

This triumphalist view of shareholders $\ddot{u} b e r$ alles in business corporations should be one

of the first casualties of a serious consideration of the nature of war in our modern, increasingly global society. ${ }^{6}$ On the contrary, the modern nature of war so forcefully brought home in the terrorist attacks on the United States on September 11, as well as the ensuing Allied military action in Afghanistan, should remind scholars in business schools, law schools, and elsewhere that corporations do not exist separately from the problems of human society. We must consider the role that business corporations play in the great games of international war and peace, as well as less deadly economic competition.

This article proceeds as follows. Part I considers the nature of war, with an emphasis on the effects of globalization and the changing importance of national boundaries. It reviews some leading theories of war and how they relate to the business corporation. In particular, it focuses on the fast, recent growth of large multinational corporations and their ascent to economic and

Convergence in Corporate Governance and Its Implications, 93 Nw. U.L. REV. 641, 650-53 (1999) (arguing against "formal convergence," but predicting "functional convergence" through securities regulation); Ronald J. Gilson, Globalizing Corporate Governance: Convergence of Form or Function, 49 AM. J. COMP. L. 329, $333-34$ (2001) (arguing against Hansmann and Kraakman's thesis of "formal convergence," but identifying other trends toward "functional," "contractual," or "hybrid" convergence that may achieve similar results). For a more direct challenge to Hansmann and Kraakman's end-of-history-in-corporate-law thesis, see Douglas M. Branson, The Very Uncertain Prospect of "Global" Convergence in Corporate Governance, 34 CORNELL INT'L L.J. 321 (2001) (arguing that this view is "chauvinistic," "Americanocentric," and supported largely only by "bald assertions").

${ }^{6}$ Not all commentators share the reductionist "shareholders only" model of the firm. See, e.g., Mark J. Roe, Rents and their Corporate Consequences, 53 STAN. L. REV. 1463, 1468, 1480 (2001) (observing that "players inside the firm - shareholders, managers, employees - compet[e] to get a piece" of the economic action and noting the existence at least in some countries of an "anti-shareholder-value ideology"); Robert B. Thompson, Shareholders as Grown-Ups: Voting, Selling, and Limits on the Board's Power to “Just Say No,” 67 U. CIN. L. REV. 999, 100506 (1999) (noting that "shareholder wealth maximization remains at the center of the purpose and objective of the corporation," but recognizing competing theories and arguing for "more precise articulation" of the meaning of "shareholder primacy" in different situations). In previous work, I have argued for a view of the business firm that includes owners (both of equity and credit), managers, and others with legal authority, including employees. Eric W. Orts, Shirking and Sharking: A Legal Theory of the Firm, 16 YALE L. \& POL'Y REV. 265, 298-314 (1998). I have also argued for theories of corporate law that include considerations beyond those of shareholders, including other constituent groups and ethical considerations. See Eric W. Orts, Beyond Shareholders: Interpreting Corporate Constituency Statutes, 61 GEO. WASH. L. REV. 14 (1992); Eric W. Orts, The Complexity and Legitimacy of Corporate Law, 50 WASH. \& LEE L. REV. 923 (1984). For a typology of different theories of "social and economic organization" that remains relevant to competing theories of corporate law, see Roberta Romano, Metapolitics and Corporate Law Reform, 36 STAN. L. REV. 923, 925-50 (1984). 


\section{William Davidson Institute Working Paper 427}

political power to rival many nation-states in comparative size and relative influence. Economic globalization and the multinational corporations that support it have significant implications for theories of modern war.

Part II turns to reconsider the perennially important topic of the nature and purposes of the business corporation in the context of modern war. It reviews the standard understanding of corporate governance involving not only economic obligations, but also legal constraints and ethical considerations. Accepted restatements of the fundamental principles of corporate law are not, as some academic commentators might prefer, encomia to the single-minded pursuit of economic values. Instead, they recognize the importance of law and ethics as components to the development of corporate purposes. In this context, the legal and ethical obligations of business corporations with respect to issues of war and peace are considered.

Part III draws some conclusions from this consideration of the nature of war and business corporations. Briefly, it argues that a serious consideration of the moral and political importance of issues of war and peace in modern society requires a major qualification to the standard lawand-economics, shareholders-only view of the corporation. An understanding the important interconnections between modern war and the business corporation reveals that theories of the social nature and purposes of business corporations have not yet reached an historical end.

To expand on Peter Gabriel's lyrics quoted at the outset, economic globalization has meant that businesses increasingly play in "games without frontiers." capabilities, as well as a hardening of hearts arguably made possible by evolution of modern

7 As Joseph White has pointed out, the metaphor of the "game" is very commonly used in business settings. B. Joseph White, Remarks at Conference on Corporate Governance, Stakeholder Accountability, and Sustainable Peace, University of Michigan Business School, Nov. 3, 2001. War is also often conceived in terms of game theories and studied through war games. See, e.g., Kenneth N. Waltz, Man, the State, And War: A THEORETICAL ANALYSIS 203-07, 223 (2001 ed.) (1959) (describing war as one game among others played by states 


\section{William Davidson Institute Working Paper 427}

forms of social organization, has also made possible "war without tears." that human society should strive against the economic, moral, and political outcome of perpetual global war, and building the institutions necessary for peace should include attention to the social structure of modern business corporations.

\section{On the Nature of Modern War}

One basic principle that has not changed is that "war not healthy for children and other living things. 9 A recent documentary estimates that two million children have been killed in wars in the last ten years. ${ }^{16}$ Tragically, as seen in Afghanistan, Africa, and elsewhere, the use of children as soldiers is "more and more common." 10 Surely, "the love of children - with their need for attention and care - is a moral bond that should transcend every local and national barrier."回 Leo Tolstoy's view remains true today: "War is not polite recreation but the vilest thing in life, and we ought to understand that and not play at war. Our attitude towards the fearful necessity of war ought to be stern and serious."13

Carl von Clausewitz probably remains the leading social theorist of war, at least since the ancient Chinese writer, Sun Tzu, and the ubiquitous European political theorist, Machiavelli. (日) $^{\circ}$

in international politics).

${ }^{8}$ One might even argue that the history of military organization into armies, navies, and other disciplined organizational forms is the story of divorcing moral sensibilities from warfare. For an argument that Western superiority on the battlefield lies precisely in its moral ability to inflict maximum destruction on enemies, see VICTOR DaVis Hanson, CARnage AND Culture: LANDMARK BAtTLES IN THE RISE OF WeStern POWER (2001).

${ }^{9}$ This slogan was a ubiquitous anti-war protest in the 1960s. See, e.g., George Packer, The Way We Live Now: Recapturing The Flag, N.Y. TIMES, Sept. 30, 2001, mag., sect. 6, at 15.

${ }^{10}$ Wendy J. William, Listening to the Children of War, BostON HeRALD, Jan. 28, 2000, at S32 (reviewing the HBO documentary, "Children in War").

${ }^{11}$ Herbert M. Howe, Global Order and the Privatization of Security, 22 FLETCHER FORUM WORLD AFFAIRS 1, 1 (1998).

12 Robert F. Drinan, S.J., The Mobilization of Shame: A World View of Human Rights 50 (2001).

${ }^{13}$ Leo Tolstoy, War AND Peace, pt. 10, ch. xxv, p. 725 (Constance Garnett trans.) [check and complete cite].

${ }^{14}$ See, e.g., Sun Tzu, The ART OF War (Samuel B. Griffith trans. 1984);Niccolò Machiavelli, The ART OF WAR (Ellis Farneworth trans. 2001). 


\section{William Davidson Institute Working Paper 427}

"War," according Clausewitz, "is an instrument of policy." takes up the sword in place of the pen." 6 For Clausewitz, writing in the early nineteenth century, war is simply politics advanced by extreme means. In his words, war is a "political instrument, a continuation of political commerce, a carrying out of the same by other means.",

Presciently, Clausewitz described war as a kind of "business competition, which is also a conflict of human interests and activities," or "still more like State policy, which again, on its part, may be looked upon as a kind of business competition on a great scale." $[8$ Interestingly, the classical theories of war advanced by Clausewitz, as well as Sun Tzu and Machiavelli, remain popular today as they are applied in the field of business strategy. ${ }^{10}$ In Clausewitz's original theory of war, however, private interests of business are properly subsumed under the larger rubric of "the interests of the whole community" - though it is possible that "policy may take a false direction" and "promote unfairly the ambitious ends" of "private interests" or "the vanity of rulers." $" 20$

In this context, business corporations - to the extent that they were just beginning to come into existence in the nineteenth century - might have been considered instruments of the nation-states in which they were based. ${ }^{1}$ In the time of Clausewitz, the size and influence of (1832).

${ }^{15}$ Carl von Clausewitz, On War 410 (J.J. Graham trans., Anatole Rapoport ed., Penguin Books 1968)

16 Id.

17 Id. at 119.

18 Id. at 202-03.

19 See, e.g., Clausewitz On Strategy: InSPIRATION AND InSIGHT From A MASTER STRATEGIST (ed. with commentary, Tiha von Ghyczy, Christopher Bassford \& Bolko von Oetinger) (2001); THE RUTHLESS LEADER: Three Classics of STRATEgy AND Power (ed. Alistair MacAlpine 2000) (including Machiavelli's The Prince and Sun Tzu's The Art of War). See also Antony Jay, Management And MACHIAVELLI: Discovering A NEW ScIENCE OF MANAGEMENT IN THE TIMELESS PRINCIPLES OF STATECRAFT (1994) (advancing a theory of business management based on Machiavelli's political theory); MARK R. MCNEILly SUN TZU AND THE ART OF BUSINESS: SIX STRATEGIC PRINCIPLES FOR MANAGERS (adapting Sun Tzu's theory to modern business strategy) (2000).

${ }^{20}$ ClausewiTZ, supra note _, at 404.

21 For general historical accounts of the development of business enterprises, including corporations, see Stuart Bruchey, Enterprise: The Dynamic Economy of a FreE People (1990); James Willard Hurst, The 


\section{William Davidson Institute Working Paper 427}

business firms were for the most part negligible. For macro-analytic purposes, business entities could be subsumed under national interests. For much of the twentieth century as well, this view of the subordinate relationship of business corporations under nation-states that were seen to give them existence, may have been sufficient, though even relatively early in the twentieth century concerns began to arise about the possibility of corporate "war merchants" influencing national politics in an belligerent direction. ${ }^{22}$ Historical evidence also suggests that wars have sometimes been fought for reasons for "a minority of financial and industrial interests" that may reap "great profit" as a result, even though overall national interests are rarely advanced by aggressive war. ${ }^{2}$ In general terms, however, the problem of war in the days of Clausewitz, and perhaps through most of the twentieth century, could be conceived adequately as a problem of "the state system" international politics. $^{24}$

Today, however, business corporations can no longer be so easily compartmentalized, and neither can the problem of modern war. Increasingly, business corporations act internationally and transnationally, citizens of the world rather than any particular nation-state. ${ }^{25}$ In about thirty years, from 1969 to 1990, the number of multinational firms more than tripled, from 7,000 to

LEGITIMACY OF THE BUSINESS CORPORATION IN THE LAW OF THE UNITED STATES, 1780-1970 (1970).

${ }^{22}$ See, e.g., ANTHONy SAMPSOn, ARMS BAZAAR: From LebANON to LockHEED (1977) (providing an overview of the international arms trade). The fear of corporate influence on policy favoring war profits is still palpable today. See, e.g., http://www.moveon.org/warprofiteering/ (visited Oct. 31, 2001) (lobbying against alternative corporate tax change on this ground).

${ }^{23}$ WALTZ, supra note _, at 145 (citing John Hobson's historical study of the Boer War, but criticizing the thesis of "imperialism" as a general cause of war). Some wars may well result when "certain well-organized business interests are able to outweigh the weak, diffused interests" in a country, but such wars of "imperialism" are "an expensive form of folly" for "the nation as a whole." Id. at 145-46 (citing and quoting Hobson).

${ }^{24}$ WALTZ, supra note _, at ix. However, some scholars have argued that capitalist state formation may encourage war. For a collection of anthropological essays along these lines, see DEADLY DEVELOPMENTS: CAPITALism, States AND WaR (S,P. Reyna \& R. E. Downs eds. 1999).

${ }^{25}$ For an overview setting up the general problem, see Eric W. Orts, The Legitimacy of Multinational Corporations, in Progressive Corporate LaW 247-66 (Lawrence E. Mitchell ed. 1995). See also PhiLIP I. Blumberg, The Multinational Challenge to Corporate LaW (1993) (describing the difficulty that globalization poses for traditional legal conceptions of the business corporation). 


\section{William Davidson Institute Working Paper 427}

$24,000 .{ }^{26}$ By 2000, the number of multinational firms had more than doubled again to 60,000, with 800,000 foreign subsidiaries. ${ }^{2}$ Multinational business now accounts for approximately one-quarter of world economic output. ${ }^{28}$ Sales of multinational-affiliated corporations are twice the value of global exports of all good and services. ${ }^{29}$ Although the number of cross-border mergers and acquisitions fell by about 50 percent in 2001, especially after the events of September 11, the slowdown followed a three-year surge in international combinations, and the trend toward global companies is likely to resume. ${ }^{\sqrt{0}}$ Two U.S.-based companies exemplify this changing reality of global corporate governance. General Electric today classifies more than 35 percent of its assets as foreign (up from only 13.5 percent in 1994), and IBM now has more than half of its total assets located overseas. ${ }^{30}$ The recent German-U.S. hybrid, DaimlerChrysler, also illustrates this trend in its recent advertising campaign featuring a single flag sewing together the smaller flags of each state and boasting that the company calls over 200 different countries “home." 驲 As a result, the concept of global “corporate citizenship" has entered the business lexicon, even if the contours of this idea are not yet clearly determined. ${ }^{3 / 3}$

Many large multinational corporations have indeed become much larger - in terms of overall economic wealth and political influence - than many nation-states. Although comparing the economic size and political muscle of business corporations and nation-states is to compare

26 Eric W. Orts, The Future of Enterprise Organization, 96 MicH. L. REV. 1947, 1963-64 (book review)

27 Stephen J. Kobrin, The End of Globalization? 6 (unpublished manuscript, on file with author) (citing United Nations statistics).

28 Id.

29 Id. For additional empirical evidence of the "importance and recent acceleration of corporate globalization," see Michael Bradley, et al., The Purposes and Accountability of the Corporation in Contemporary Society: Corporate Governance at a Crossroads, 62 LAW \& ConTEMP. PROB. 9, 14-21 (1999).

30 Joseph Quinlan, No Stopping the Global M\&A Train, FIN. TIMES, Nov. 12, 2001, at 24.

31 Id.

32 http://www.daimlerchrysler.de/index_e.htm (visited Nov. 14, 2001).

33 For recent treatments in the business literature, see CORPORATE GLOBAL CITIZENSHIP: DoING BUSINESS IN The Public Eye (Noel M. Tichy et al. ed., 1998); MAlcolm McIntosh, ET AL., CorPorate Citizenship: 


\section{William Davidson Institute Working Paper 427}

apples with oranges, one can nevertheless say with assurance that the relative size and influence of business corporations has increased dramatically in recent years compared with nation-states. According to one recent study that makes the comparison, fifty-one of the one hundred largest integrated economic entities in the world today are business corporations; the remaining fortynine entities are nation-states. ${ }^{3}$ More than twenty years ago, another observer argued that "the largest corporations overshadow all save about a dozen of the nation-states of the planet" in terms of "totality of assets.", 5 In terms of raw measurements of economic size and power, large corporations dwarf many smaller nation-states. ${ }^{\sqrt{6}}$ As a result, "significant decisions affecting people everywhere" are increasingly "made by corporate managers, not political officers." large "void" with respect to business corporations has therefore opened "at the intersection of national boundaries that is very difficult to manage and control.",3[

Descriptively, then, we may criticize Clausewitz's view of the world as too simple and old-fashioned. What Jürgen Habermas calls a "new postnational constellation" has arisen - the creation of economic, political, and cultural forces of globalization. ${ }^{19}$ Here, globalization means "a process" that "characterizes the increasing scope and intensity of commercial, communicative, and exchange relations beyond national borders."

SUCCESSFUl STRATEGIES FOR RESPONSIBLE COMPANIES (1998).

34 NoreEnA Hertz, The Silent TAKEOVER: THE Rise of CORPORATE POWER AND THE DeATH OF DEMOCRACY _ (2002) [forthcoming]. See also John Kay, FinANCIAL TimES, Aug. 22, 2001 (available at http://www.johnkay.com/articles/) (reviewing Hertz's claim).

${ }^{35}$ Arthur Selwyn Miller, The Modern Corporate State 223 (1976).

${ }^{36}$ [add cite and example].

${ }^{37}$ Id.

38 Bradley, et al., supra note _, at 31.

39 See Jürgen Habermas, The Postnational Constellation: Political Essays 60-61. See also Martin L. VAN CReVeld, The Rise And Decline of The State 336-421(1999) (describing the "decline of the state" in recent years and the need to confront a new political reality "beyond the state").

${ }^{40}$ HABERMAS, supra note _, at 65-66. 


\section{William Davidson Institute Working Paper 427}

air travel, and digital communications" characterize this process. 4 One might even say that the "process" of globalization has reached the status of "a condition - a globality, a world economy in which the traditional and familiar boundaries are being surmounted or made irrelevant." ${ }^{2}$ As described by Selya Benhabib, "global integration in the sphere of economics, armament, finance, communication, information, and tourism [has] proceeded with a dizzying pace." ${ }^{\text {, }}$ New risks come with this process of globalization, including not only the advent of new and potent brands of international terrorism, but also global ecological challenges, global financial risks, and other collective action problems for social organization. ${ }^{4}$

Mark Duffield describes these emerging patterns as "paradoxes of globalization.”"[5 The "changing competence of the nation-state," according to Duffield, results in "a shift" from a reliance on hierarchical national governments to "wider and more polyarchal networks, contracts and partnerships of governance." 6 Globalization raises problems of political accountability and democratic legitimacy. ${ }^{4}$ Considerations of economics becomes elevated over politics in many areas. $^{48}$ In addition, globalization seems to occur in tandem with an increase in "cultural, ethnic, linguistic, [and] religious separatisms and demands for local and regional autonomy.",

41 Id. at 66.

42 Daniel Yergin \& Joseph Stanislaw, The COMmanding Heights: The Battle Between GOVERnMENT AND THE MARKETPLACE THAT Is REMAKING THE MODERN WORLD 14 (1998). Little of substance seems to turn on a distinction between globalization as a "process" or "condition."

43 Selya Benhabib, Political Theory and Political Membership in a Changing World 5 (unpublished manuscript on file with author) (forthcoming in Political SCIENCE: THE STATE OF THE DisciPLinE (Ira Katznelson \& Helen Milner eds., 2001)).

${ }^{44}$ Id. See also Ulrich Beck, Globalization's Chernobyl, FIN. TIMES, Nov. 6, 2001, at 15 (surveying the global risks that the events of September 11 exposed).

${ }^{45}$ Mark Duffield, Geography and the Boundaries of Confidence: Globalization and War Economies: Promoting Order or the Return of History? 23 FLETCHER FORUM OF WORLD AFFAIRS J. 21 (1999).

46 Id. at 23.

47 Id.

48 Id. For a description and analysis of the recent "shift" in emphasis from political states to economic markets, see Yergin \& Stanislaw, supra note __, at 11-17, 125-51, 369-91.

${ }^{4}$ Benhabib, supra note __, at 5. 


\section{William Davidson Institute Working Paper 427}

Globalization thus transforms the nature of war. ${ }^{\text {[ }}$ According to Martin van Creveld, the

post-Westphalian period of the dominance nation-states and the paradigm of war as primarily

involving conflict among nation-states is now ending. 5 In van Creveld's words,

The state, which since the middle of the seventeenth century has been the most important and most characteristic of all modern institutions, is in decline. From Western Europe to Africa, many existing state are either combining into larger communities or falling apart. ... Globally speaking, the international system is moving away from an assembly of distinct, territorial, sovereign, legally equal states toward different, more hierarchical, and in many ways more complicated structures. As far as individual states are concerned, there are good reasons to think that many of them will soon no longer be either willing or able to control and protect the political, military, economic, social, and cultural lives of their citizens to the extent that they used to. Needless to say, these developments affect each and every individual now living on this planet. In some places, these will proceed peacefully, but in others they are likely to result in - indeed are already leading to upheavals as profound, and possible as bloody as those that propelled humanity out of the Middle Ages and into the modern world. ${ }^{5[}$

In a globalized society, simplified versions of Clausewitz no longer apply. Instead, nation-states are losing their grip on their monopolies of violence. Global society may be returning to a world characterized by complex struggles in which "political, social, economic, and religious motives" become "hopelessly entangled." 绍 If so, then we may well expect the return to prominence of "mercenaries" and "swarms of private armies" such as those that characterized the period of the Reformation and the Thirty Years' War in Europe. ${ }^{\text {. }}$ (

Perhaps the leading contemporary theorist of war, John Keegan, agrees with the premises of this diagnosis. According to Keegan, war has become too expensive for modern rich states to

${ }^{50}$ For a leading recent treatment of this topic, see MARTIN L. VAN CREVELD, THE TRANSFORMATION OF

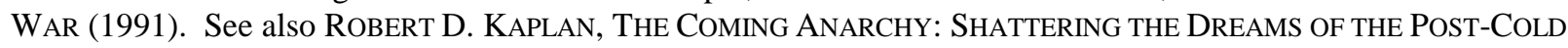
WAR WORLD 43-49 (2000) (discussing van Creveld's theory of war and its influence on the Pentagon's thinking about war in the twenty-first century).

51 See KAPLAN, supra note _, at 46 (describing van Creveld's views).

${ }^{52}$ VAN CREVELD, supra note _ _ [The Rise and Decline of the State], at vii.

${ }_{54}$ KAPLAN, supra note __, at 46 (quoting van Creveld).

54 Id. 


\section{William Davidson Institute Working Paper 427}

wage against each other in its "full potentiality," but it has also "become, paradoxically, a cheap and deadly undertaking for poor states, for enemies of the state idea, and for factions in states falling apart." 5 Rather than states, we therefore face new kinds of enemies. "The rogue ruler, the terrorist and the fundamentalist movement, the ethnic or religious faction," Keegan writes, "are all enemies as serious as any, in an age of junk weapons, as civilization has ever faced.",66 In other words, new technologies and the political challenges of war in a modern, globalized world have changed significantly. Limited rather than unlimited war becomes the rule, rather than the exception. ${ }^{56}$ As General Wesley Clark writes, military actions in this "difficult region" are "not quite war - not quite peace."

At the same time that Keegan recognizes technological and political changes in the nature of modern war, however, he criticizes Clausewitz's traditional conception on normative grounds. Keegan sees Clausewitz as producing "the most pernicious philosophy" of war "yet conceived" because it views war as "a value free activity, outside the moral sphere." catastrophes of the "short" twentieth century and its two global wars provide graphic evidence that Clausewitz was mistaken in thinking that the "rational" calculations of national interests by states would limit warfare.

Important implications for a contemporary moral perspective on war follow from its new

55 JOHN KEEGAN, WAR AND OUR WORLD 68 (1998).

$56 \mathrm{Id}$.

57 Wesley K. Clark, Waging Modern War: Bosnia, Kosovo, and the Future of Combat 418-19 (2001) (describing NATO's intervention in Serbia and Kosovo as a "limited war" of a kind likely to be repeated in the future).

58 Id. at 458. In this middling region between unlimited war and international criminal police actions, Clark includes "limited war, pre-and post-conflict operations, and 'nation building." Id.

59 Id. at 41-42.

${ }^{60}$ For Keegan, Clausewitz's theory therefore at least implicitly provided a justification for the totalitarian state. Id. at 42. For an account of "the short twentieth century" as including the "catastrophe" of two world wars, see HABERMAS, supra note _, at 37-57. As Waltz argues, Rousseau had, prior to Clausewitz, made a convincing theoretical case that nation-states acting in their own self-interests - even as aggregated in a "general will" - have 


\section{William Davidson Institute Working Paper 427}

globalized character. War changes over time. 6 "Like a disease," again according to Keegan, “it exhibits the capacity to mutate, and mutates fastest in the fact of efforts to control or eliminate it." " Keegan defines war as "collective killing for some collective purpose." "6 It retains a "a scourge-like nature . . . to threaten the very survival of civilization itself.",6

From the perspective of the business corporation, this account of the modern, globalized nature of war suggests several important issues. First, business corporations have increasingly become "detached" from nation-states in their everyday operations. The driving force of this process of globalization is fundamentally economic rather than political. ${ }^{\text {d5 }}$ "Nation-states do not trade with one another," as two commentators argued recently with some overstatement, "enterprises do." 6 Because business corporations are fundamental to the globalization process, they are also key to understanding the changed nature of the disease of modern war and its possible antidotes.

Second, the central role of business enterprises in globalization means that they cannot avoid becoming implicated in global issues of war and peace. If not to the same extent as the nation-states that field great armies, business corporations often have occasion to ally with states in using force and even hire military help independently of states. Moreover, if nation-states cannot protect businesses, then business people will seek other ways to protect themselves. An example may be found in contemporary Russia, where hiring a private security agency is counted

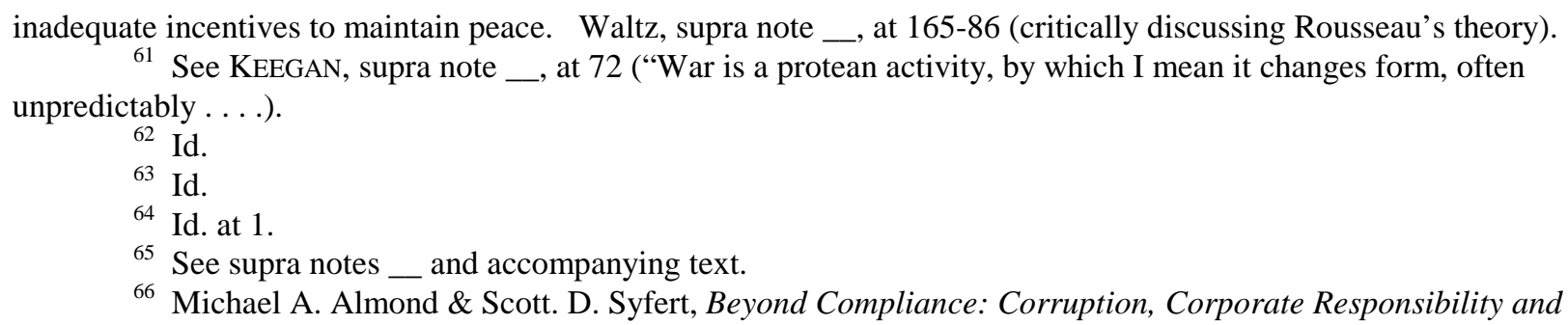
Ethical Standards in the New Global Economy, 22 N.C. J. IN'TL L. \& COMM. REG. 389, 402 (1997). 


\section{William Davidson Institute Working Paper 427}

as the normal course of doing business. ${ }^{6}$ Indeed, the rise of private security companies in the world at large is an immense growth industry, which seems to illustrate both a decline of the protective powers of political states and an increase in business responses to social insecurity. ${ }^{6}$

Third, the decline of the relative influence of nation-states means that the "new enemies" of international society - including terrorists, as well as organized crime - may use corporate and other business organizational forms for illicit ends. A chilling recent example is the "corporate" organization of the Al Qaeda terrorist network. ${ }^{6}$ International channels and methods of business may be employed for illicit political and economic purposes, and new organizational responses to these threats are required.

Fourth, the nature of modern war highlights the fact that business corporations are not only abstract economic entities but social institutions. As organized institutions composed of human beings, they have moral and political as well as economic responsibilities. Like states, business corporations must therefore develop their own foreign and domestic policies, either implicitly and even unconsciously or, much better, explicitly and with awareness. This does not mean that large, global corporations need to appoint new vice presidents of war or defense; but it does require corporate leaders to take the larger global issues of war and peace seriously from a moral as well as an economic perspective. In a "postnational" world, business corporations can no longer simply rely on nation-states to take of problems of international security - if, indeed, they ever could delegate this responsibility entirely.

\footnotetext{
${ }^{67}$ [add cite] See also infra text accompanying notes _ (discussing the rise of "private military companies").

${ }^{68}$ For statistics on the exponential growth of the private security business in Europe and the United States, see VAN CREVELD, supra note _ [The Rise and Decline of the State], at 404.

69 See Kurt Eichenwald, Terror Money Hard to Block, Officials Find, N.Y. TIMES, Dec. 10, 2001, at __;
} 


\section{William Davidson Institute Working Paper 427}

\section{On the Nature and Purposes of Business Corporations}

Milton Friedman has memorably expressed one common understanding of the nature and purposes of the modern business corporation. In general, according to Friedman, corporate executives have the responsibility "to make as much money as possible while conforming to the basic rules of the society, both those embodied in law and those embodied in ethical custom.", , Unpacking this approach into a more formal analytical framework, the American Law Institute's Principles of Corporate Governance states that (a) the "objective" of a corporation is "the conduct of business activities with a view to enhancing corporate profits and shareholder gain" and (b) legal and ethical considerations qualify this economic objective. ${ }^{2}$ Specifically, there are at least three qualifications. First, "[e]ven if corporate profit and shareholder gain are not thereby enhanced, the corporation, in the conduct of its business ... [i]s obliged, to the same extent as a natural person, to act within the boundaries of the law." account ethical obligations that are reasonably regarded as appropriate to the responsible conduct of business." $\sqrt{3}$ And third, a corporation may "devote a reasonable amount of resources to public

Dan Van Natta, Jr., Running Terrorism as a New Economy Business, N.Y. Times, Nov. 11, 2001, at _.

70 Milton Friedman, The Social Responsibility of Business Is to Increase Its Profits, N.Y. TIMES, Sept. 13, 1970, mag., at 32 .

71 American Law InStitute, PRINCIPLES OF CoRporate GovernanCE: ANALYSIS AND RECOMMENDATIONS $§ 2.01$ (1994). Although intended to be "consistent with case law," Section 2.01 has "sparked controversy" among commentators. Bradley, et al., supra note _, at 48. As my colleague, Alan Strudler, emphasized in discussions with me, the ALI's restatement of the corporate objective as "enhancing corporate profits and shareholder gain" is not synonymous with Friedman's injunction "to make the most money possible." The latter seems to lead to an imperative of "shareholder value maximization," while the softer verb "enhance" seems to allow for non-maximizing value strategies (including profit "satisficing") and perhaps even the addition of multiple objectives, including what the ALI formally structures as exceptions to the economic objective, namely, socially responsible objectives of following the law and acting ethically. The ALI's "enhancing corporate profits and shareholder gain" language is probably best interpreted as a compromise between contending views of the business corporation in society. If correct, this interpretation would provide further evidence that "end of history" in corporate law has not been reached. Academic debates can and should continue about the proper place of corporate governance within the larger society.

72 AMERICAN LAW INSTITUTE, supra note _, at $§ 2.01(b)(1)$.

73 Id. $§ 2.01(b)(2)$. 


\section{William Davidson Institute Working Paper 427}

welfare, humanitarian, educational, and philanthropic purposes." ${ }^{1}$ Modern war raises concerns on all three levels related to the corporate objective: economic, legal, and ethical. ${ }^{75}$

\section{A. War and the Economic Objective}

On the purely economic dimension, private corporations may seek to make profits and enhance shareholder value by engaging in the business of war, that is, manufacturing and selling weapons, munitions, and military services. Recent activities in this industry give a sense of the scale of this business. On October 27, 2001, the U.S. Defense Department awarded the largest military contract in American history to Lockheed Martin Corporation in the amount of $\$ 200$ billion for the building of a new Joint Strike Fighter supersonic stealth jet. ${ }^{\text {目 }}$ Also in October 2001, the U.S. Justice Department blocked a proposed friendly acquisition of Newport News Shipbuilding by General Dynamics valued at $\$ 2.6$ billion on the grounds that the deal would create a monopoly in the construction and sale of nuclear-powered submarines and aircraft carriers. ${ }^{7}$ The government prefers a merger between Newport News and Northrup Grumman. News of the September 11 bombing of the World Trade Center and the Pentagon sent military stocks upwards. ${ }^{2}$ Similar, though perhaps smaller, connections between business corporations and national military budgets apply to both companies and countries outside the United States. ${ }^{80}$ Clearly, there is much money still to be made in war, and today business corporations act as the

74 Id. $\$ 2.01(\mathrm{~b})(3)$.

75 Although my analysis in this part will draw primarily on U.S. examples, the general issues are relevant also for law and business corporations in other countries with appropriate amendments.

${ }^{76}$ Edward Alden, Lockheed Wins \$200bn Pentagon Project, Fin. TIMES, Oct. 27/28, 2001, at 1; James Dao \& Laura M. Holson, Lockheed Wins \$200 Billion Deal for Fighter Jet, N.Y. TIMES, Oct. 27, 2001, at A1. The loser was Boeing Corporation. See also Alexander Nicoli, Aerospace Companies Scramble in Their Biggest Dogfight Yet, FIN. TiMES, Oct. 23, 2001, at 8.

77 Edward Alden et al., Newport News Sale Is Blocked, Fin. Times, Oct. 24, 2001, at 21; Edward Alden, Contractor Falls Found of New Dynamic in Defence Thinking, Oct. 25, 2001, at 20.

78 Id.

[add cites]

${ }^{80}$ [add citations and perhaps some statistics] 


\section{William Davidson Institute Working Paper 427}

primary vehicle for the purpose.

Special issues of law and ethics arise in military contracting. Billion-dollar contracts

must create great temptations for corporate executives or other employees to fudge the rules on political lobbying and fair economic competition. The regulation of government procurement contracts has therefore been traditionally very detailed. ${ }^{\text {I }}$ In the United States, a large Defense Contract Auditing Agency oversees defense procurement. ${ }^{8}$ [ Companies themselves recognize the special nature of the legal and ethical problems they face, and the defense industry in the United States has organized a voluntary Defense Industry Initiative on Business Ethics and Conduct.

Another important issue involves the regulation of financial contributions to political campaigns. ${ }^{84}$ Although it is not illegal for business corporations to contribute to the political process, the question arises whether a military contractor should, as a matter of policy, have significant influence in choosing political leaders. At least arguably, the economic objective should not allow corporations in the business of war to support candidates with particularly aggressive foreign policy agendas. But these issues slide into the topic of legal and ethical constraints on the economic objective. Before considering these important areas, however, I would like to mention one troubling trend that raises the issue of whether business corporations should sometimes be banned from engaging in at least some kinds of military profit-making.

${ }^{81}$ For a good overview of the regulation of the federal government procurement contracting process, with criticism of Clinton Administration reforms, see Steven L. Schooner, Fear of Oversight: The Fundamental Failure of Businesslike Government, 50 AM. U.L. REV. 627 (2001).

${ }^{82}$ See http://www.dcaa.mil/ (visited October 29, 2001).

83 See http://www.dii.org/ (visited December 14, 2001). The Defense Industry Initiative includes "a set of six principles drafted by the representatives from eighteen defense contractors that called for specific compliance procedures, policies, and programs, e.g., codes of ethics, ethics training, and internal reporting practices." William S. Laufer, Corporate Liability, Risk Shifting, and the Paradox of Compliance, 52 VAND. L. REV. 1343, 1348 (1999).

${ }^{84}$ For general treatments of the jurisprudence of regulation of corporate campaign contributions, which involves First Amendment restrictions, see Jill E. Fisch, Frankenstein's Monster Hits the Campaign Trail, 32 WM. \& MARY L. REV. 587 (1991); Thomas J. Woo, The Modern Corporation and Campaign Finance: Incorporating Corporate Governance into First Amendment Jurisprudence, 79 WASH. U. L. Q. 1 (2001). 


\section{William Davidson Institute Working Paper 427}

This trend relates to the recent increase in what have been called "private military companies" (PMCs). ${ }^{45}$

In June 1997, the Pentagon held a conference on the "privatization of security" in subSaharan Africa. ${ }^{86}$ Members of a new growth industry of PMCs were on display, as well as the private security representatives of some large oil companies, such as Texaco and Exxon. ${ }^{87}$ For example, Military Professional Resources, Incorporated (MPRI) claims "the greatest corporate assemblage of military expertise in the world," including seventeen retired U.S. generals as well as hundreds of former U.S. Special Forces personnel. ${ }^{8 / 8}$ Vinnell Corporation is another example. It employs approximately 1,000 former U.S. military personnel in training 65,000 members of the Saudi National Guard, the personal security contingent protecting the Saudi Royal family. ${ }^{80}$ Executive Outcomes (EO) is a South African company that fields thousands of combat soldiers in sub-Saharan Africa. EO's air capabilities include a fleet of helicopters and MIG fighter jets. 요

The existence and use of PMCs raises a central question with respect to the economic objective of corporate law. Unlike informal or ad hoc networks of mercenary armies in the past, PMCs today have developed a "distinct corporate nature," including "a desire for good public relations." 回 But are corporate "soldiers of fortune" to be accepted as just another way of doing business? At least, the issue of the intrinsic legitimacy of these kinds of businesses arises. A

${ }^{85}$ Craig Forcese, Deterring "Militarized Commerce": The Prospect of Liability for "Privatized" Human Rights Abuses, 31 OtTAWa L. Rev. 171, 174 (1999/2000). See also David Shearer, Outsourcing War, ForeIGN POL'Y, (Fall 1998) at 68 (describing the rise of private military companies).

${ }^{86}$ Forcese, supra note _, at 174.

${ }^{87}$ Id. Not surprisingly, the private security business has been a growth industry in the post-September 11 world. See Al Baker, Fear Feeds Bull Market in Private Security, N.Y. TIMES, Oct. 29, 2001, at D1. A distinction should be drawn, however, between private security firms operating within the legal framework of a national state and firms with transnational scope and include military services.

${ }^{88}$ Howe, supra note _, at 2.

${ }^{89}$ Id. Vinnell is a subsidiary of TRW Corporation based in Fairfax, Virginia. See http://www.vinnell.com/ (visited October 29, 2001).

${ }^{90}$ Howe, supra note _, at 2. 


\section{William Davidson Institute Working Paper 427}

primary aspect of the claim to legitimacy by political states involves the assumed monopoly on military force that they exercise. Private military companies threaten to erode this monopoly of coercive force. The economic objective of maximizing shareholder value does not compare favorably with theories of political democracy as a legitimate basis for the use of military force. A good argument can made, therefore, for an international agreement to ban PMCs, though the social forces of globalization may make such an agreement difficult to achieve. At the same time, it is accurate to observe that the rise of PMCs responds to "the pullback of western nations and the United Nations from peacekeeping and peace enforcing" missions, especially in poor or developing countries. ${ }^{\text {g日 }}$ At least, the international community should seek to regulate the actions and behavior of PMCs, probably through an international treaty - in other words, through the development of morally informed legal constraints. ${ }^{\text {栭 }}$ Already in the United States, for example, some regulation is provided under the Arms Export Control Act and the Export Administration Act. $^{\text {沟 }}$ The Arms Export Control Act provides conditions for the foreign sale of U.S. goods and services, and the Export Administration Act regulates the export and sale of so-called "dual-use" material that has both civilian and military applications. 55 Similar controls are imposed in other countries. $^{96}$ International regulation of private companies engaged in the actual provision of military services as "modern mercenaries," however, is lacking, if not entirely absent.

\section{B. Legal Constraints on the Business of War}

Contrary to what one might assume from a strict shareholders-only view of the business corporation, the accepted general rule in the United States is that a corporation has an obligation

\footnotetext{
91 Id.

92 Id. at 5.

93 Id. at 7.

94 Id.

95 Id. n. 18.
} 


\section{William Davidson Institute Working Paper 427}

to follow the law, in the words of the American Law Institute, "to the same extent as a natural person.”团 The Reporters' comments on this requirement make clear that “cost-benefit analysis,” though it may have an appropriate role in government determinations about the adoption of legal rules, should not apply to a corporation's own decision whether or not to comply with the law. Because "the resulting legal rule normally represents a community decision that the conduct is wrongful as such," then “cost-benefit analysis whether to obey the rule is out of place.”, ,

This requirement to follow the law even if it is not economically convenient to do so is mandatory, in contrast to the permissively formulated ethical and philanthropic qualifications. ${ }^{96}$ The Principles of Corporate Law recognize, however, that the requirement to follow the law finds its own justification in the "moral norm of obedience to law."10 The legitimacy of this norm derives in turn from the democratic legitimacy of governments that enact the law. ${ }^{10}$ As Melvin Eisenberg, a Reporter for the American Law Institute's Principles explains: “Ours is a society of law. We don't want a society in which the major players - that is, corporations - are lawless."10

Several complications with what Eisenberg calls this "legal-conduct principle" arise in practice. $^{10}$ First, in a globalized world, corporations will often find themselves subject to

${ }^{96}$ [add examples]

97 AMERICAN LAW INSTITUTE, supra note _, § 2.01(b)(1).

98 Id. $§ 2.01(\mathrm{~b})(1) \mathrm{cmt}$. g.

99 A commentator on early drafts of Section 2.01 made the point that it "consists of a mixture of mandates and aspirations." Donald E. Schwartz, Defining the Corporate Objective: Section 2.01 of the ALI's Principles, 52 GeO. WASH. L. REV. 512, 513 (1984). The obligation to the follow the law is expressed as a "mandate," while the ethical and philanthropic provisions are "permissive." Id.

100 AMERICAN LAw InSTITUTE, supra note _, $\$ 2.01(\mathrm{~b})(1), \mathrm{cmt} . \mathrm{g}$.

101 The legitimacy of law is a large and complex jurisprudential topic. For one of my attempts to grapple with the issue, see Eric W. Orts, Systemic Legitimacy and Positive Law: A Comment on Hart and Habermas, 6 RATIO JURIS 245 (1993).

102 Melvin Aron Eisenberg, Corporate Conduct that Does Not Maximize Shareholder Gain, 28 STETSON L. REV. 1, 3 (1998).

103 Id. at 3. 


\section{William Davidson Institute Working Paper 427}

inconsistent regulations. One may say, as Lockheed Martin does in its Code of Ethics and

Business Conduct, that a corporation will "obey all the laws of the countries in which we do business."14 But this promise does not account for hard choices that have to be made when laws of different countries conflict. In the case of a major government contractor like Lockheed Martin, one assumes that loyalty to its "home country" of the United States outweighs conflicting laws of other countries, but this choice requires a moral judgment. ${ }^{105}$ It is not merely a technical question of conflicts of laws.

Second, even with respect to following one set of national laws, complex regulations may mean that it is practically impossible to comply with all regulations all of the time. One example comes from environmental law, where corporate compliance officers find keeping abreast of changing regulations difficult and full compliance with them impossible. ${ }^{16}$ The same difficulty may arise in the complex legal environment of military contracting. To take Lockheed Martin again as an example, the corporation recognizes that "laws and regulations related to government contracting are far-reaching and complex, thus placing responsibilities on Lockheed Martin beyond those faced by companies without government customers," but the company nevertheless promises to "conduct our business in accordance with all applicable laws and regulations. 107 Complying with potentially conflicting regulations in different countries also complicates these problems. In Lockheed's recently awarded contract for the Joint Strike Fighter, the company

104 http://www.lockheedmartin.com/exeth/html/code/print.html (visited October 29, 2001).

105 At the time of this writing, Lockheed Martin's homepage included a link to a series of patriotic video tributes as well as the announcement of a new Lockheed Martin American Spirit Fund to provide charitable contributions for relief to New York, Washington, and other regions affected by the September 11 attacks. See http://www.lockheedmartin.com/ (visited October 29, 2001). The site leaves no doubt about the company's national loyalty.

106 See Eric W. Orts, Reflexive Environmental Law, 89 Nw. U.L. REv. 1227, 1240-41 \& n.55 (1995) (surveys show most participants do not believe that full compliance with all environmental laws was even possible). ${ }^{107} \mathrm{http}: / /$ www.lockheedmartin.com/exeth/html/code/print.html (visited October 29, 2001). 


\section{William Davidson Institute Working Paper 427}

will have to comply with both U.S. and U.K. laws. ${ }^{108}$

Third, the question of obeying the law "to the same extent as a natural person" raises the question of the scope of the comparative standard. If most "natural persons"disobey the law speed limits on highways, for example - then may corporate decision makers follow the same strategy? ? $^{10}$ Many examples in this category are trivial, but "natural persons" certainly often take risks in not following the law, accepting the risks that if they get caught, they will pay the fine or penalty. Arguably at least, business corporations should enjoy a similar freedom of action. ${ }^{110}$ Lastly, the moral obligation to obey the law does not always trump other more basic moral obligations. The topic of potential conflicts between the obligations of law and morality is a very large one. ${ }^{1}$ Suffice it to say here that a corporation engaged in the business of war may sometimes face serious moral considerations that require abstention from following a law or even affirmative civil disobedience of an unjust law or a tyrannical government. To take one example, corporations doing business within Nazi Germany cannot claim simply to have been "following the law" to justify war profits. ${ }^{11}$ Similarly, corporations today must make judgments about the

108 See supra note _ and accompanying text.

109 For a hypothetical along these lines involving setting corporate policy to comply (or violate) different state limits for the weight of trucks traveling on highways, see WiLliAM A. KLEIN, ET AL., BUSINESS AssociATIONS 349-50 (2000).

${ }^{110}$ On the other hand, one can argue that corporate policies to disobey the law - even for a presumably trivial reason like speeding or parking tickets - should be treated more severely because of the organizational and deliberate nature of a decision about policy, rather than seat-of-the-pants decisions by natural persons to comply with traffic laws (or not).

111 For useful overviews of the basic issues, see KENT GREENAWALT, CONFLICTS OF LAW AND MoRALITY (1987); The Duty to Obey the Law: Selected Philosophical Readings (William A. Edmundson ed. 1999).

112 Claims against firm that employed slave labor during the Nazi regime include not only prominent German corporations such as Bayer, BMW, Krupp, Siemens, and Volkswagen, but also American firms with German subsidiaries such as Ford, General Motors, Exxon-Mobil, and Kodak. See Kara C. Ryf, Note, Burger-Fischer v. Degussa AG: U.S. Courts Allow Siemens and Degussa to Profit from Holocaust Slave Labor, 33 CASE W. RES. J. INT'L L. 155, 156-58 (2001). See also John Christopher Anderson, Respecting Human Rights: Multinational Corporations Strike Out, 2 U. PA. J. LABOR \& EMPLOYMENT L. 463, 469 (2000) (noting that Bayer has admitted to using slave labor during the Nazi period, while BMW, Volkswagen, and Siemens have been accused of similar behavior); Stuart M. Kreindler, Comment, History's Accounting: Liability Issues Surrounding German Companies for the Use of Slave Labor by Their Corporate Forefathers, 18 DICK. J. INT'L L. 343 (2000) (discussing 


\section{William Davidson Institute Working Paper 427}

morality of doing business with various nation-states and other actors for different purposes. ${ }^{1 \sqrt{3}}$

Following the law is not a sufficient reason to act immorally, and this principle applies even

more strongly to fundamental problems of war and peace than other circumstances where the

stakes for human beings and their fundamental rights may be smaller.

Moral obligations to avoid complicity in unjust wars may also lead to changing legal

standards for liability. Thus, for example, the extension of liability under the Alien Tort Claims $\operatorname{Act}^{11}{ }^{1}$ and Torture Victim Prevention Act ${ }^{115}$ may reflect a general movement toward increasing international enforcement of basic human rights. ${ }^{116}$ Cases have begun to recognize causes of action for the breach of internationally recognized human rights (jus cogens) in the United States and elsewhere. $^{11 日}$ For example, the leading case of Filartiga v. Pena-Irala ${ }^{10}$ held "deliberate torture perpetrated under color of official authority" to be actionable under the Alien Tort Claims

the circumstances of various lawsuits filed against German companies in the United States); Kevin M. McDonald, Corporate Civil Liability Under the U.S. Alien Tort Claims Act for Violations of Customary International Law During the Third Reich,1997 ST. LOUIS-WARSAW TRANSATLANTIC L.J. 167 (2000) [add parenthetical]. In one recent case, a court sustained a cause of action brought for Nazi-era crimes against a Germany subsidiary of Ford. Iwanowa v. Ford Motor Co., 67 F. Supp. 2d 424 (D.N.J. 1999).

In the Nuremberg Trials, a showing of "necessity" under compulsion or duress was allowed as a defense for some individual defendants who were businesspeople found to have employed slave labor to further the economic interests of the Nazi regime. But this defense was not permitted to defendants who had "embraced the opportunity" or expressed an "ardent desire" to employ slave labor. See Doe v. Unocal, 110 F. Supp.2d 1294, 1309-1310 (C.D. Cal. 2000) (discussing three Nuremberg cases).

113 One interesting development has been the increasing tendency of political subdivisions of the nationstates - such as the "states" of the United States - to assert political restrictions on business operations. For examples and an overview of the constitutional issues involved, see Edward T. Swaine, Negotiating Federalism: State Bargaining and the Dormant Treaty Power, 49 DUKE L.J. 1127, 1129-47 (2000).

11428 U.S.C. $\S 1350$ [check cite].

11528 U.S.C. $\$ 1350$ [check cite].

116 See DrinAN, supra note _, at 95-103; Anderson, supra note _, at 491-96. See also Kathryn L. Boyd, Collective Rights Adjudication in U.S. Courts: Enforcing Human Rights at the Corporate Level,1999 B.Y.U.L. REV. 1139 (arguing for use of class actions to enforce human rights violations by corporations abroad).

117 For a discussion of the general problem, see Christopher A. Ford, Adjudicating Jus Cogens, 13 WIS. INT'L L.J. 145 (1994). But see Curtis A. Bradley, Customary International Law and Private Rights of Action,1 CHI. J. INT'L L. 421 (2000) (arguing that a "second wave" of post-Filartiga private human rights actions based on customary international law have largely failed with respect to U.S. defendants). For a critique of the development of universal legal principles such as jus cogens, see Alfred P. Rubin, Actio Popularis, Jus Cogens, and Offenses Erga Omnes? 35 NEW ENG.L. REV. 265 (2001).

118630 F.2d 876 (2d Cir. 1980). 


\section{William Davidson Institute Working Paper 427}

Act as a violation of "universally accepted norms of international law of human rights."11日 More recently, in Kadic v. Karadzic, ${ }^{120}$ the Second Circuit Court of Appeals upheld a claim against a private citizen under the Alien Tort Claims Act for a violation of international legal prohibitions against war crimes and genocide. ${ }^{12 ⿴}$ Radovan Karadzic, a Bosnian-Serb, had been served process when he visited the United Nations in New York. ${ }^{12}$ He was accused of genocide, war crimes, and other human rights violations committed against Croatian and Muslim citizens of BosniaHerzegovina. $^{1 \sqrt{3}}$ The court upheld the action against a motion to dismiss for failure to state a claim under the principles of Filartiga, finding with respect to the "state action" requirement that the plaintiffs had adequately alleged Karadzic to be acting either on behalf of an embryonic "state" or "in concert" with Serbia (i.e., the former Yugoslavia). ${ }^{124}$ The court noted also in dicta that the U.S. Supreme Court had previously upheld claims against private individuals under the Alien Tort Claims Act. ${ }^{1 \sqrt{5}}$ Pirates, slave traders, or other types of "hostis humani generis (an enemy of all mankind)" have been held accountable for violations of international legal norms. ${ }^{16}$ Doe v. Unocal Corporation ${ }^{12}$ provides an example of how extraterritorial liability for violations of international law may eventually apply to business corporations. In Unocal, the

119 Id. at 878.

12070 F.3d 232 (2d Cir. 1995).

121 Id. at 236.

122 Id. at 237.

123 Id. at 236. The allegations included "various atrocities, including brutal acts of rape, forced prostitution, forced impregnation, torture, and summary execution, carried out by Bosnian-Serb military forces as part of a genocidal campaign." Karadzic was alleged to have "ultimate command authority" over these military forces. Id.

124 Id. at 244-45.

125 Id. at 239 (citing early cases against piracy).

126 Id. at 239 (quoting In The Brig Malek Adhel, 43 U.S. (2 How.) 210, 213 (1844). See also Tel-Oren v. Libyan Arab Republic, 726 F.2d 774, 794-95 (D.C. Cir. 1984) (Edwards, J., concurring) (arguing that individual liability was available under the Alien Tort Claims Act for some acts including piracy and slave trading). Pirates and their ilk, of course, are as old as human civilization. See, e.g., ThUCYDIDES, ThE PELOPONNESIAN WAR bk. I 37 (Rex Warner trans., Penguin ed. 1972) (recounting that Minos was "the first person to organize a navy" to combat "piracy," which had become "a common profession" in ancient Greece).

12710 F. Supp. 2d 1294 (C.D. Cal. 2000). 


\section{William Davidson Institute Working Paper 427}

company and its officials were sued under the Alien Tort Claims Act for violations of human rights in a joint venture with a French oil company, Total N.A., in Myanmar (Burma). ${ }^{128}$ The court granted summary judgment to the defendants on the ground that the official "state action" requirement of the Alien Tort Claims Act had not been met. ${ }^{129}$ But the facts of the case suggest a close call. The U.S. State Department had warned Unocal (and Total) of forced labor (otherwise known as slavery) by Myanmar, and the Myanmar army, which agreed to undertake a "security" role in the gas pipeline project, had a history of violations of human rights. ${ }^{1: 0}$ One of Unocal's own consultants had written a letter warning that

My conclusion is that egregious human rights violations have occurred, and are occurring now, in southern Burma. The most common are forced relocation without compensation of families from land near/along the pipeline route; forced labor to work on infrastructure projects supporting the pipeline ([euphemistically called] government services in lieu of payment of taxes); and imprisonment and/or execution by the army of those opposing such actions. Unocal, by seeming to have accepted [the Myanmar army's] version of events, appears at best naive and at worst a willing partner in the situation. ${ }^{13 t}$

\section{Human Rights Watch, Amnesty International, and Greenpeace confronted Unocal executives}

about its complicity in the project and were ignored. ${ }^{1: 2}$ In the end, the district court granted summary judgment under a strict reading of the "state action" requirement of the Alien Tort Claims Act and concluded that the plaintiffs had presented "no evidence that Unocal participated

${ }^{128}$ Id. at 1295 . In a separated proceeding, Total was dismissed from the action on grounds of lack of personal jurisdiction. Doe v. Unocal Corp., 248 F.3d 915 (9th Cir. 2001).

129110 F. Supp.2d at 1304-10. In its legal analysis, the court drew on questionable comparisons to the "state action" requirements in federal civil rights cases. Id. at 1305-07. The court does not explain why "state action" in the context of international violations of human rights should be compared with "state action" requirements in the enforcement on national civil rights. The "states" in question are quite different.

${ }^{130}$ Id. at 1296-98, 1302. Unocal's CEO admitted understanding that the Myanmar army would "provide general security" for the project, but denied any knowledge of "any contract" to this effect. Id. at 1301.

131 Id. at 1299-1301. Unocal's counsel even argued that the forced "government services in lieu of payment of taxes" could be justified under a post-Civil War precedent that upheld a state's requirement "to work on roads and bridges for ten hours a day for six days per year or pay \$3 [in tax]." Id. at 1308 (citing Butler v. Perry, 240 U.S. 328 (1916). The court rightly rejected this argument as "hardly analogous." Id.

132 Id. at 1300 


\section{William Davidson Institute Working Paper 427}

in or influenced' the military's unlawful conduct."13 ${ }^{3}$ No evidence revealed an explicit contract, agreement, or "conspiracy" between Unocal and the Myanmar government to violate human rights through forced labor and relocation. ${ }^{12}$ However, in reaching its result, the court discussed the Nazi-era Nuremberg cases against the wartime German industrialists to apply the relevant international legal principles. ${ }^{136}$ At least, it appears that the Unocal executives stepped over the moral if not the legal edge of acceptable behavior in knowing about and benefitting from human rights violations in the pursuit of its economic objectives. The holding of Doe v. Unocal is also arguably in tension with the Second Circuit's recognition of the potential liability of private citizens without a state action requirement in Kadic v. Karadzic. ${ }^{136}$ Business corporations in the future would be well-advised legally as well as ethically to steer clear of business relationships with governments or its military forces that operate outside the pale of international recognition and acceptability. ${ }^{13 日}$ Although Doe v. Unocal Corp. may be narrowly interpreted as a corporate victory against human rights claims, few business corporations would wish to have to rely on Nazi-era precedents and good lawyering to win summary judgment in similar circumstances. If the case reached a jury, the outcome would most likely be unpleasant for shareholders as well as corporate executives.

133 Id. at 1306.

134 Id. at 1306-10.

135 Id. at 1310. Three cases at Nuremberg involved prosecutions of German industrialists for war crimes. Defendants convicted were two executives in the German steel industry, five executives of the I.G. Farben chemicals company, and twelve member of the Krupp corporation. Id. $t$ 1309-11 (citing Nuremberg cases).

${ }^{136}$ See supra note __ and accompanying text (noting private liability of hostis humani generis for human rights violations under international law).

137 For further discussion of the Unocal case and its implications, see Craig Forcese, Note, ATCA's Achilles Heel: Corporate Complicity, International Law and the Alien Tort Claims Act, 26 YALE J. INT'L L. 487 (2001); Pia Zara Thadhani, Note, Regulating Corporate Human Rights Abuses: Is Unocal The Answer?, 42 WM \& MARY L. REV. 619 (2000); Leslie Wells, A Wolf in Sheep's Clothing: Why Unocal Should be Liable Under U.S. Law for Human Rights Abuses in Burma, 32 Colum. J.L. \& Soc. ProBs. 35 (1998). For further general discussion and recommendations, see also David I. Becker, Note, A Call for the Codification of the Unocal Doctrine, 32 CORNELL INT'L L.J. 183 (1998); Gregory G.A. Tzeutschle, Note, Corporate Violator: The Alien Tort Liability of Transnational Corporations for Human Rights Abuses Abroad, 30 Colum. Human Rights L. REV. 359 (1999). 


\section{William Davidson Institute Working Paper 427}

\section{Ethical Constraints on the War Business}

Even if Unocal's dealings with the Myanmar army did not rise to the level of a violation of international human rights as a legal matter, it also illustrates that basic moral understandings should constrain corporate conduct. ${ }^{138}$ It is difficult to see how Unocal can morally justify its actions in Myanmar given repeated warnings from government officials and nongovernmental organizations of persistent practices of slave labor, forced relocations, and other human rights violations. Unocal's complicity may not quite reach the moral baseness of actively cooperating with Nazis, but the company's actions come close. Moral shame and blame should therefore accrue. $^{1: 9}$

If the pipeline in Myanmar were not enough, the Unocal Corporation also provides another lesson in how to choose the wrong business partner when it negotiated an arrangement with the Taliban in Afghanistan to help protect construction of a planned oil pipeline across the country in the 1990s. This deal, fortunately for the company, was abandoned by 1999, perhaps in part as a result from political pressure from feminist groups, but more likely as a consequence of the rising infamy of Osama bin Laden. ${ }^{140}$ Few, if any, corporations can maintain that it is ethical to make deals with terrorists. Like pirates or Nazis, international terrorists belong to the category of hostis humani generis. ${ }^{14 ⿴ 囗 十 ~}$ If doing business with terrorists is not a violation of international law, it arguably should be.

138 A similar analysis may apply to the French company, Total, as well.

139 Cf. DRINAN, supra note _. Cf. also David A. Skeel, Shaming in Corporate Law, 149 U. PA. L. REV. 1811 (2001) (discussing the importance of shaming in corporate governance, but with different ends in view).

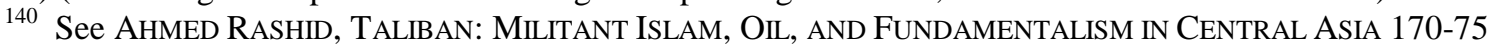
(2000). But cf. Milton Bearden, Afghanistan, Graveyard of Empires, ForEIGN AFFAIRS (Nov.-Dec. 2001), at 17, 26 (recognizing the U.S. firms had abandoned hopes of building an Afghanistan pipeline with Taliban support by 1997).

141 See supra note _ and accompanying text. For the controversial argument that IBM knowingly stepped over the moral line in its business dealings with Nazi Germany, see EDWIN BLACK, IBM AND THE HolOCAUST: THE Strategic Alliance between NAZi Germany AND AmeriCA's Most Powerful Corporation (2001). 


\section{William Davidson Institute Working Paper 427}

In addition to following the law, both Milton Friedman and the Principles of Corporate

Governance recognize ethical constraints on business beyond formal legal requirements. ${ }^{14}$

Ethical business practices do not begin and end with the law. Again as Melvin Eisenberg writes, Section 2.01's discussions of "ethical considerations" express a common sense understanding about corporate governance: "We don't want a society in which people are encouraged to become amoral when they become corporate executives. We don't want a society in which managers check their ethics at the door."14⿴囗⿱一一

Another example from an illustration in the Principles of Corporate Governance and adapted further by Eisenberg in a recent article should be sufficient to prove the general point that compulsory moral obligations should sometimes constrain a corporate action even when it is not technically illegal.

142 Again, Friedman and the ALI do not use similar terms. See supra notes _ and accompanying text. Friedman's reference to "ethical custom" is much more general than the ALI's discussion of various ethical qualifications.

${ }^{143}$ Eisenberg, supra note __, at 5. 


\section{William Davidson Institute Working Paper 427}

Corporation D is a large publicly held corporation engaged in the manufacture of powerful computers, with annual earnings of \$ 60-70 million. D has been negotiating with a North African country for the sale of three computers. Negotiations were essentially complete, and a contract ready to sign, when the State Department announced that within the next few days the President would adopt an executive order prohibiting the shipment of certain high-technology products to that country, because its conduct was highly inimical to the United States and threatened the stability of the entire area. In other words, the State Department was going to add the country to a list of states that sponsored international terrorism. The State Department announced, however, that the formal legal prohibition would not be applied to contracts made before the order became effective, but urged voluntary compliance as of the date of the announcement. It was clear that when the executive order became effective it would apply to D's computers. D estimates that the sale would generate earnings of $\$ 6$ million, and that short- and long-term costs entailed by completing the sale would not be significant. D nevertheless decides not to sign the contract, because its officials believe that sale of the computers would contravene a strong and clearly announced national policy. D's action is not only proper but ethically compelled. $^{14}$

I have changed the facts slightly - adding the ethical "hot button" of a State Department listing of the North African country as a state sponsor of international terrorism. But this change is only designed to make moral point of the revised outcome more convincing. Although the American Law Institute's commentary suggests that D might be allowed to sign such a contract under the principle of following its economic objective, ${ }^{14 E}$ it does not require much argument to convince most managers that entering such a contract would be unethical and, indeed, morally prohibited.

This example also provides an illustration of how Section 2.01 of the ALI's Principles of Corporate Governance does not exhaust the analysis required of corporate managers, especially high-level executives. Section 2.01 recognizes "ethical obligations that are reasonably regarded as appropriate to the responsible conduct of business," 146 which echoes Milton Friedman's allowance for "ethical custom."1日 But notice the circularity in both of these formulations.

144 Adapted from Eisenberg, supra note _, at 7-8, adapted in turn from AMERICAN LAW INSTITUTE, supra note _, $\$ 2.01$, illus. 21 , at 69 .

145 AMERICAN LAW InSTITUTE, supra note _, $§ 2.01$, illus. 22, at 69.

146 See supra note _ and accompanying text.

147 See supra note _ _ and accompanying text. 


\section{William Davidson Institute Working Paper 427}

Someone must make the ethical decisions that eventually become "reasonably regarded" by the business community as "ethical customs." The example of Corporation D's computer sales to a country that knowingly "harbors terrorists," as well as many other real-world cases such as Unocal's investment in Burma, indicate that much moral ground remains to be tilled to determine the appropriate ethical conduct in transnational business. Answers to tough moral business problems cannot rely solely on the experience of previous generations or entrenched customs. Previous moral answers themselves have sources in basic principles and reasoning, and new moral situations require fresh reasoning if not new principles to resolve. "Following the crowd" is not an acceptable ethical strategy.

\section{Permissive Business Ethics and War}

The third and last exception to the economic objective provided in Section 2.01 permits corporations to "devote a reasonable amount of resources [that is, donate] to public welfare, humanitarian, educational, and philanthropic purposes." 14 This exception is recognized in socalled charitable contribution statutes in almost all states. ${ }^{140}$ Commentators have added the limitation of "reasonableness," presumably to curtail corporations from acting too lovingly, especially when the love for some is expressed by giving away other people's money. ${ }^{150}$

Again, Eisenberg gives a good example of the permissive ethical exception relevant to present circumstances.

[S]uppose America is at war. C Corporation devotes corporate resources for the purpose of furthering the war effort, rather than for maximizing the profits on the commodities it

\footnotetext{
148 AMERICAN LAW InSTITUTE, supra note __, $§ 2.01(\mathrm{~b})(3)$.

149 Id. Reporter's Note at 72.

150 Id. See also Prunty, supra note _.
} 


\section{William Davidson Institute Working Paper 427}

produces and then sells - for example, by holding down prices to prevent inflation. ${ }^{1}$ 回 Eisenberg argues that corporate behavior supporting the war effort may have a rational economic justification if "it is in the economic interest of all American corporations that America should win the war."1月 Then, business corporations would face a collective action problem - or prisoner's dilemma - but if they coordinated their actions and "all devoted resources to the war effort, they would all be better off."1级

This argument is correct, as far as it goes. But notice that some complications that arise on closer examination of Eisenberg's example. The economic interests of different corporations may quickly diverge in a war economy. Different corporations may thus have different economic interests in going along with a collective effort to support a war. In other words, collective action problems arise for the political effectiveness of moral exhortations to sacrifice profits for war. ${ }^{150}$ More importantly, Eisenberg's example of C Corporation provides an illustration of the permissive ethical principle. For a just war, a business corporation may provide a "reasonable" amount of support. Lockheed Martin, for example, again provides a contemporary example in having setting up a "American Spirit Fund" initially supported with a corporate donation of \$1

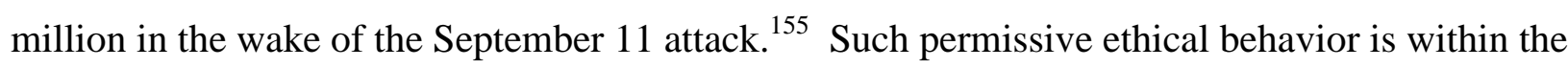
standard ethical understanding of the nature and purposes of the corporation. Indeed, many state statutes explicitly authorize corporations to depart from the economic objective for the purposes of contributing resources to the public welfare "in time of war or other national emergency." 156

151 Eisenberg, supra note _, at 12.

152 Id.

$153 \mathrm{Id}$

154 For discussion of these limitations, see WALTZ, supra note __, at 193-96 \& n.11.

155 See supra note __ [giving website].

156 See Delaware GeNERAl CORP. LAW $\S 122$ [add date] ( corporations "shall have the power to . . . make donation in the public welfare ... and in time of war or other national emergency in aid thereof. ..."); NEW YORK 


\section{William Davidson Institute Working Paper 427}

The clear moral issues presented by the prospect of participating in war helps to clarify the moral issues faced by business corporations in Section 2.01. Following the incisive analysis of Donald Schwartz, one should distinguish between (a) ethical constraints that are arguably imposed by Section 2.01's admonition that corporate managers "may take into account ethical considerations that are reasonably regarded as appropriate to the responsible conduct of business" and (b) permissive ethical behavior that allows for a corporation affirmatively to contribute "a reasonable amount of resources" to charities, education, public welfare, or other philanthropic or humanitarian causes. ${ }^{15 t}$ Although both ethical constraints and ethical permissions are exceptions to the profit-making economic objective relate to moral principles, the distinction between them makes sense in terms of the gravity of different kinds of ethical decisions.

In many situations, moral philosophers argue that it is worse to commit a serious wrong than to avoid doing a good act. To put the idea in philosophical terms: Other things being equal, directly causing harm is very often worse than allowing harm to occur. ${ }^{158}$ A common example discussed in philosophy is the difference between "killing and letting die."159 Both are bad, but intentional killing is usually thought to be worse than various inactions that could have saved lives. $^{180}$ Murder, for example, is morally worse than failing to give a donation that may save the lives of starving people in Afghanistan. In the context of war and corporate governance, then, it

BUSINESS CORP. LAW $\S 202(a)(12)$ [add date] (corporations have the power "to make donations, irrespective of corporate benefit, for the public welfare . . and in time or war or other national emergency in aid thereof. ..."). In addition, corporate constituency statutes in Florida, Ohio, and other states include "the economy of the state and nation" as among the various interests that corporate directors and managers may consider in making business decisions. E.g., OHIO REV. CODE $§ 1701.59(\mathrm{E})(2)$.

${ }_{158}^{157}$ See supra note _ and accompanying text.

158 See, e.g., WARREN QUINN, MORALITY AND ACTION __ (1993) [complete cite].

159 For a recent collection of essays on the topic, see KILLING AND LETTING DIE (Bonnie Steinbock \& Alastair Norcross, 2d ed., 1994).

160 The distinction between killing and letting die is often considered a specific instance of a more general distinction between doing and allowing. Alistrair Norcross, Introduction, KILLING AND LETTING DIE, supra note __, at 9 . 


\section{William Davidson Institute Working Paper 427}

seems worse to contribute weapons of war to a tyrannical regime that result in the unjustified deaths of many people than to fail to make charitable contributions to good cause in society (including the cause of a just war or good government). The philosophical complications in this area are considerable and require references to specific situations to work out correctly, but for the purposes here it is enough to show that Section 2.01's division between what might be though of as ethical duties - and permissions - may make substantive philosophical sense. The world is morally complicated (as well as complicated in many other ways). Therefore, it makes sense to identify clear moral constraints as opposed to moral permissions. The former, of course, should be taken much more seriously when a person (or corporation) faces a choice of action. ${ }^{1} 11$ Still, one worries about the fact that Section 2.01 refers to moral constraints themselves only as "permissive."16 One might interpret this provision to allow for quite evil corporate acts as long as they are legal. Only a cursory reflection on the problems of war crimes, genocide, and other major human rights violations discussed above, should be sufficient to dispel this notion. Probably, Section 2.01 should recognize that at least some moral requirements are imperative, not merely "permissive" or "voluntary." The ALI's Principles of Corporate Governance err on the side of caution by avoiding a straightforward statement that corporations must adhere to

161 The distinction between moral constraints and permissions does not correspond with a further subset of ethically "superogatory" behavior. This term is used to refer to unusually good or heroic behavior of a kind that most people cannot be expected to perform. Very brave acts for good ends in the face of grave risks of death, for example, are praised but not expected as a rule. In the terms employed here, a corporation could act in a "superogatory" fashion in promoting, for example, a peaceful world above and beyond the expectations of the public. But this would be a kind of permissive ethical behavior; other permissive ethical behavior may be expected such as some form or amount of corporate charitable contribution - that is not superogatory.

162 The ALI's official comment goes so far as to state explicitly that "Section 2.01(b)(2) does not impose a legal obligation to take ethical considerations into account.” AMERICAN LAW INSTITUTE, supra note _, $§ 2.01 \mathrm{cmt}$. $\mathrm{h}$ at 64 . It goes on to say that "the absence of a legal obligation . . . does not mean that corporate decisionmakers are not subject to the same ethical obligations of other members of society." Id. But this double-negative construction does not make the statement in favor of corporate ethical obligations very strong. Moreover, in some cases, particular when the support of wars may be involved, corporations may in fact have greater responsibilities than ordinary citizens in making ethical decisions whether or not to support given military activities, given the likelihood of their decisions having a larger social impact. 


\section{William Davidson Institute Working Paper 427}

ethical as well as legal constraints. But this strategy is dangerous given that some business corporations inevitably face great ethical responsibilities that bear in matters of war and peace. At least, corporate lawyers (and legal and business academics) should make clear that following the law - or even following the crowd - does not permit a corporation to transgress foundational moral boundaries.

\section{War and Economics: Toward the Institution of Peace?}

Even the most hard-bitten law-and-economist must admit when pressed that stark moral choices posed by war should constrain business enterprises. In modern societies, a business corporation may have a primary objective of "enhancing corporate profit and shareholder gain," but this objective is grounded on an implicit assumption of relative peace. In other words, the profit-seeking objective of a business corporation must find its limits in the political will of democratic states as expressed in positive law. When the peaceful legal framework is shattered by war, then even the limits of law are insufficient. Doing business with pirates, slave traders, or terrorists cannot be morally justified, even if international law cannot yet reach these wrongs. Conspiring or cooperating with Nazis or Al Qaeda cannot be morally condoned.

Even though nothing is said of the values and principles of political democracy in the Principles of Corporate Governance, these values and principles are implicit in the exception to the "economic objective" given by the "boundaries set by law." 1 3 The "ethical considerations" mentioned generally by the American Law Institute are also essential to determining the actions that business corporations may and should take when faced with situations of war or situations that are likely to involve fighting wars. These are principles that should find international scope and application. 


\section{William Davidson Institute Working Paper 427}

Corporate decisions to participate in and profit from war - even for a just cause - carry moral as well as legal responsibility. In commenting on U.S. military participation in the war against Serbia on behalf of Kosovo, an American law professor perceptively observed: “As I read the national pulse, what Americans don't want is for their children to be sent into harm's way to guarantee higher profits for corporations. ..."16 Wars and corporate participation in wars must have a higher moral and political justification than profit and shareholder gain.

The larger justifications for war include basic moral and political principles of freedom, democracy, and peace. I will not attempt here to argue for which of these higher principles may be necessary or sufficient to justify violent conflict and intentional killing. ${ }^{185}$ Contemplation of the truth of modern war - and the participation of business corporations in it - should convince even the most economically-oriented legal theorists that some higher moral values must play a significant role in contemporary corporate law and governance - at least when matters of war and peace are at stake. Business corporations, as well as nation-states and individual citizens, cannot avoid confronting important moral issues of responsibility when they participate actively in war.

Finally, to conclude on a more positive note, the institutions of business - including business corporations and the competition of organized markets - may contribute to a social psychological solution to the long-standing problem of war in human society. On one hand, modern business corporations supply the means of modern war. They may profit from war, and

163 See supra note _ a and accompanying text [quoting ALI text].

164 Robert F. Turner, Kosovo: Legal and Policy Implications, 10 U.S. AIR ForCE ACAD. J. LEGAL STUD. 67, 85 (1999/2000).

165 For leading treatments of the political and ethical problems of war, see WALTZ, supra note _ ; MICHAEL WALZER, JUST AND UNJUST WARS (1977). For a more recent discussion, agreeing with Walzer that even just wars must be fought with ethical restraint, see WARD THOMAS, THE ETHICS OF DESTRUCTION: NORMS AND FORCE IN INTERNATIONAL RELATIONS (2001). 


\section{William Davidson Institute Working Paper 427}

this fact raises a very difficult political issue of isolating the business interests of "the military industrial complex" from political decision making about war and peace. ${ }^{166}$ On the other hand, business competition may also provide what William James called "the moral equivalent of war" needed for the permanent institution of peace. ${ }^{18}$ "History is a bath of blood," observes James. 18 Today - after two world wars have been fought since James wrote his famous essay - some still say "peace" when they mean "war expected" or even "permanent, unceasing" war. 1 d9 Building a global civilization that includes competitive business enterprises and economic markets may, perhaps, point the direction toward a "substitute for war's disciplinary function," as well as its psychological and even aesthetic attractiveness to human beings. ${ }^{1}$ [ By taming the business corporation, we might also tame ourselves.

William James also observed that "war-making is due to definite motives and subject to prudential checks and reasonable criticisms, such like any other form of enterprise." ${ }^{\text {tI }}$ Business corporations have been instruments of war, but they can also serve the cause of "the institution of peace."17 In a globalizing and increasingly interdependent world, there is a strong argument for “an intellectual duty to proclaim the inconceivability of war." ${ }^{\text {极 }}$ To do so, however, does not itself advance the practical conditions of peace. ${ }^{1 \text { 因 }}$ Building institutions of peace will require,

166 Dwight D. Eisenhower, Farewell Radio and Television Address to the American People, Jan. 17, 1961, Public Papers of the Presidents of the United States: Dwight D. Eisenhower 1038 (1961) [check cite].

167 William James, The Moral Equivalent of War, in BEST AMERICAN ESSAYS OF THE CENTURY 45 (Joyce Carol Oates ed. 2000) (1910).

168 Id. at 46.

169 Id. at 47. Even Plato said that "peace" was only another name for "incessant" war. PLATO, LAWS, 1.626A (quoted in Victor DAVIS HANSON, CARNAGE AND CUlTurE: LANDMARK BATTLES IN THE RISE OF WESTERN POWER 440 (2001)).

170 James, supra note _ at 51.

171 Id. at 52.

172 Cf. Michael Howard, The InVEntion of PEACE: Reflections on WAR AND International ORder (2001).

173 UMberto ECO, Five Moral PIECES 16 (2001).

174 For a strong practical argument along these lines, see WALTZ, supra note __, at __ [complete cite]. 


\section{William Davidson Institute Working Paper 427}

again in the words of James, a "a future when acts of war shall be outlawed as between civilized peoples." ${ }^{17}[\mathrm{E}$ New and improved structures of international law, including "institutionalized restraints and institutionalized methods of altering and adjusting interests," will be required. ${ }^{1 / 6}$ This future civilization, however, will also need large business corporations not only to perform an economic objective, but also to abide by the law and to act ethically. Then, perhaps we can hope to establish at least improved probabilities for “a reign of peace."1杨

\section{Conclusion}

Sadly and tragically, peace will not come without the collective monopolization of force that makes war possible. The threat of new enemies, including international terrorists, "requires that the responsible powers, committed to ... peace, must be able to deploy forces of the highest quality, human as well as technological, to any part of the globe at all times." ${ }^{8}$ Clausewitz writes memorably that

If bloody slaughter is a horrible spectacle, then it should only be a reason for treating war with more respect, but not for making the sword we bear blunter and blunter by degrees from feelings of humanity, until once again someone steps in with a sword that is sharp and hews away the arms from our bodies. 19

Business corporations therefore have an essential role to play in the enterprise of peace, even as they contribute to the modern armories of war, but they - and the social and political institutions that regulate them - must take their responsibilities seriously and with the proper ethical gravity. War is not merely a game for business to play for profits. If war is a game, it is a very serious one that requires ethics and legal regulation as well as economics.

175 James, supra note _, at 52-53.

176 WALTZ, supra note_, at 231.

177 James, supra note __, at _.. As Waltz argues, it may ask too much to hope for a true and everlasting peace on earth. But we might at least in improve the odds by "decreasing the incidence of war" and "increasing the chances of peace." WALTZ, supra note _ , at 1.

${ }^{178}$ KeEGAN, supra note _, at $\overline{68}$. 


\section{William Davidson Institute Working Paper 427}

In this article, I have not provided many practical answers to the question of how business corporations can be better regulated or how business executives can make better moral decisions with respect to war. But I hope at least to have raised these issues as serious ones deserves of academic and practical attention. Useful future research may include the following list of topics:

- What current national and international regulations constrain corporate profitmaking in supply the goods and services of war? How can national laws such as the Arms Export Control Act and the Export Administration Act be improved or supplemented? What lessons may be learned from other countries? What would a comparative study of these laws recommend in terms of possible international regulation in this area?

- $\quad$ Should special laws constrain the participation of military-related businesses in political lobbying and campaign financing? If so, how?

- $\quad$ How should the Alien Tort Claims Act and Torture Victim Prevention Act be interpreted or amended with respect to claims against business corporations, as well as individuals, by victims of human rights violations? How would such interpretations or amendments either promote peace or be counterproductive to this end?

- Should the novel and growing form of "private military companies" that appear to be in the thriving business of providing mercenary military services be regulated at the international level? If so, how? Are there benefits to private military companies in a world in which the relative power of nation-states is declining?

- $\quad$ How should the law of corporate governance - both national and international be changed to reflect a realistic and humane conception of the important of business corporations in matters of war and peace, as well as the promotion of economic well-being? How can corporate executives be given the flexibility to act ethically on these issues, without giving them the latitude to abuse their power and authority?

- What are the current best practices of corporations in the defense industry in terms of ethical and legal compliance programs? How can ethical and legal behavior in the defense industry be encouraged both nationally and internationally?

- What kinds of ethical issues do different companies in different businesses related 


\section{William Davidson Institute Working Paper 427}

to warfare face? What does the emerging discipline of business ethics offer in terms of rational approaches to solving these ethical dilemmas?

- How can business corporations act permissibly, within their legal power, to promote global peace as well as prosperity? How could superogatory or heroic corporate actions in promoting peace be recognized or rewarded? 


\section{DAVIDSON INSTITUTE WORKING PAPER SERIES - Most Recent Papers}

The entire Working Paper Series may be downloaded free of charge at: www.wdi.bus.umich.edu

CURRENT AS OF $1 / 18 / 02$

\begin{tabular}{|c|c|c|}
\hline Publication & Authors & Date \\
\hline No. 427: War and the Business Corporation & Eric W. Orts & Dec. 2001 \\
\hline $\begin{array}{l}\text { No. 426: Partial Privatization and Firm Performance: Evidence from } \\
\text { India }\end{array}$ & Nandini Gupta & Dec. 2001 \\
\hline $\begin{array}{l}\text { No. 425: Direct Foreign Investments and Productivity Growth in } \\
\text { Hungarian Firms, 1992-1999 }\end{array}$ & Jérôme Sgard & Nov. 2001 \\
\hline $\begin{array}{l}\text { No. 424: Banking Passivity and Regulatory Failure in Emerging } \\
\text { Markets: Theory and Evidence from the Czech republic. }\end{array}$ & Jan Hanousek and Gerard Roland & July 2001 \\
\hline $\begin{array}{l}\text { No. 423: Conceptions of the Corporation and the Prospects of } \\
\text { Sustainable Peace }\end{array}$ & Jeffrey Nesteruk & Dec. 2001 \\
\hline No. 422: The Role of the Corporation in Fostering Sustainable Peace & Timothy Fort and Cindy Schipani & Nov. 2001 \\
\hline No. 421: Wage Arrears and the Distribution of Earnings in Russia & $\begin{array}{l}\text { Hartmut Lehmann and Jonathan } \\
\text { Wadsworth }\end{array}$ & Dec. 2001 \\
\hline $\begin{array}{l}\text { No. 420: Transferring Collective Knowledge: Collective and } \\
\text { Fragmented Teaching and Learning in the Chinese Auto Industry }\end{array}$ & $\begin{array}{l}\text { Jane Zhou, Jaideep Anand, and } \\
\text { Will Mitchell }\end{array}$ & Dec. 2001 \\
\hline $\begin{array}{l}\text { No. 419: Liberalization, Corporate Governance, and the Performance of } \\
\text { Newly Privatized Firms }\end{array}$ & $\begin{array}{l}\text { Narjess Boubakri, Jean-Claude } \\
\text { Cosset, and Omrane Guedhami }\end{array}$ & Dec. 2001 \\
\hline $\begin{array}{l}\text { No. 418: The European Data Privacy Directive and International } \\
\text { Relations }\end{array}$ & Steven R. Salbu & Dec. 2001 \\
\hline $\begin{array}{l}\text { No. 417: Capital Markets and Capital Allocation: Implications for } \\
\text { Economies in Transition }\end{array}$ & $\begin{array}{l}\text { Artyom Durnev, Randall Morck, } \\
\text { and Bernard Yeung }\end{array}$ & Dec. 2001 \\
\hline $\begin{array}{l}\text { No. 416: Forthcoming in: The Journal of Economic Perspectives, "Data } \\
\text { Watch. Research Data from Transition Economies," 16(2) Feb. } 2002 .\end{array}$ & $\begin{array}{l}\text { Randall K. Filer and Jan } \\
\text { Hanousek }\end{array}$ & Dec. 2001 \\
\hline $\begin{array}{l}\text { No. 415: Forthcoming in: The Journal of Economic Perspectives, } \\
\text { "Transition Economies: Performance and Challenges," 16(2) Feb. } 2002 .\end{array}$ & Jan Svejnar & Dec. 2001 \\
\hline $\begin{array}{l}\text { No. 414: Forthcoming in: The Journal of Economic Perspectives, "The } \\
\text { Great Divide and Beyond: Financial Architecture in Transition," 16(2) } \\
\text { Feb. 2002. }\end{array}$ & Erik Berglof and Patrick Bolton & Dec. 2001 \\
\hline $\begin{array}{l}\text { No. 413: Forthcoming in: The Journal of Economic Perspectives, "The } \\
\text { Political Economy of Transition," 16(2) Feb. } 2002 .\end{array}$ & Gérard Roland & Dec. 2001 \\
\hline $\begin{array}{l}\text { No. 412: The Response of Consumption in Russian Households to } \\
\text { Economic Shocks }\end{array}$ & Steven Stillman & Oct. 2001 \\
\hline No. 411: Mark-ups in Hungarian Corporate Sector & László Halpern and Gábor Körösi & Aug. 2001 \\
\hline No. 410: Economic Development, Legality, and the Transplant Effect & $\begin{array}{l}\text { Daniel Berkowitz, Katarina } \\
\text { Pistor, Jean-Francois Richard }\end{array}$ & Sept. 2001 \\
\hline No. 409: Development Strategy, Viability, and Economic Convergence & Justin Yifu Lin & Oct. 2001 \\
\hline No. 408: Labor Supply, Informal Economy and Russian Transition & Maxim Bouev & May 2001 \\
\hline No. 407: Corporate Governance in China: Then and Now & Cindy Schipani and Liu Junhai & Nov. 2001 \\
\hline No. 406: Entrepreneurship and Post-Socialist Growth & $\begin{array}{l}\text { Daniel Berkowitz and David N. } \\
\text { DeJong }\end{array}$ & Oct. 2001 \\
\hline $\begin{array}{l}\text { No. 405: Forthcoming in: European Economic Review, "Policy Reform } \\
\text { and Growth in Post-Soviet Russia." }\end{array}$ & $\begin{array}{l}\text { Daniel Berkowitz and David N. } \\
\text { DeJong }\end{array}$ & Oct. 2001 \\
\hline $\begin{array}{l}\text { No. 404: Social Policies and Structures: Institutional Frictions and Traps } \\
\text { in the Czech Republic after } 1989\end{array}$ & Jiří Večerník & Nov. 2001 \\
\hline $\begin{array}{l}\text { No. 403: Investment, Efficiency, and Credit Rationing: Evidence from } \\
\text { Hungarian Panel Data }\end{array}$ & Mathilde Maurel & Nov. 2001 \\
\hline $\begin{array}{l}\text { No. 402: Subduing High Inflation in Romania. How to Better Monetary } \\
\text { and Exchange Rate Mechanisms? }\end{array}$ & $\begin{array}{l}\text { Daniel Daianu and Radu } \\
\text { Vranceanu }\end{array}$ & Aug. 2001 \\
\hline $\begin{array}{l}\text { No. 401: The Gender Wage Gap in Bulgaria: A Semiparametric } \\
\text { Estimation of Discrimination }\end{array}$ & Dean Jolliffe & July 2001 \\
\hline
\end{tabular}

